\title{
Localized Renal Cell Carcinoma Management: An Update
}

\author{
Flavio L. Heldwein, T. Casey McCullough, Carlos A. V. Souto, Marc Galiano, Eric Barret
}

Department of Urology, Institut Montsouris, Paris, France

\begin{abstract}
Objective: To review the current modalities of treatment for localized renal cell carcinoma.

Materials and Methods: A literature search for keywords: renal cell carcinoma, radical nephrectomy, nephron sparing surgery, minimally invasive surgery, and cryoablation was performed for the years 2000 through 2008 . The most relevant publications were examined.

Results: New epidemiologic data and current treatment of renal cancer were covered. Concerning the treatment of clinically localized disease, the literature supports the standardization of partial nephrectomy and laparoscopic approaches as therapeutic options with better functional results and oncologic success comparable to standard radical resection. Promising initial results are now available for minimally invasive therapies, such as cryotherapy and radiofrequency ablation. Active surveillance has been reported with acceptable results, including for those who are poor surgical candidates.

Conclusions: This review covers current advances in radical and conservative treatments of localized kidney cancer. The current status of nephron-sparing surgery, ablative therapies, and active surveillance based on natural history has resulted in great progress in the management of localized renal cell carcinoma.
\end{abstract}

Key words: renal cell carcinoma; treatment; nephrectomy; surgical procedures; minimally invasive Int Braz J Urol. 2008; 34: 676-90

\section{INTRODUCTION}

Renal cell carcinoma (RCC) is the third most frequent urologic cancer and represents $2-3 \%$ of all adult malignancies. Adenocarcinoma is the most prevalent histologic subtype, responsible for approximately $85 \%$ of renal tumors (1). Historically, RCC was known as the tumor of multiple presentations due to the several signs and symptoms that could be present at the time of diagnosis. Currently, up to $40 \%$ of kidney neoplasms are detected incidentally because of the widespread use of imaging technologies (2). This has led to an apparent increase in the incidence of RCC (3).

For decades, radical nephrectomy was considered the gold standard treatment for localized RCC, representing the only curative option. Several open or laparoscopic approaches are now available. However, despite a small improvement in overall survival and good oncologic outcomes, radical surgery has a relapse rate that can reach $30 \%$ (4). Likewise, renal function outcomes can be poor, even in patients with a normal contralateral kidney. More recently, renal parenchyma preservation and nephron-sparing procedures are beginning to demonstrate satisfactory results, pointing toward a possible role of new minimally invasive energy-based ablation techniques in renal tumor therapy.

\section{EPIDEMIOLOGY}

World statistics show 208,000 new renal cell carcinoma cases/year and 102.000 deaths/year (1). 
There is a geographical prevalence variation. The smallest incidence rates have been observed in Africa, Pacific Coast and Asia (except for Japanese men). In some countries, such as Denmark and Sweden the incidence has been decreasing for the last 20 years (5).

In Latin America, the highest incidence is observed in Uruguay and in the south of Brazil (Porto Alegre 10.2 per 100.000 men) (6), contrasting with low rates in the north of Brazil and in the middle-west area, Goiania for instance $(7,8)$.

According to the American Cancer Society, more than 54,390 new cases and 13,010 deaths are expected in 2008 in the United States. Since 1950, the annual incidence has grown by $130 \%$, at a rate of $3.7 \%(9)$.

Data from the U.S. Surveillance, Epidemiology and End-Results (SEER) study shows that 54\% of renal tumors are organ confined at diagnosis, 20\% are locally advanced and $25 \%$ of the patients already have disseminated disease. Approximately $50 \%$ of these patients will develop metastases. The 2-year survival rate for patients with untreated metastases is only $0-20 \%(10)$. In general, global survival rates at 5 and 10 years are $65 \%$ and $56 \%$, respectively.

\section{TREATMENT}

\section{The Trial Search Strategy}

The computerized database of the US National Library of Medicine of the search engine PubMed (http://www.pubmed.gov), and the Latin American and Caribbean Health Sciences LILACS database were primarily searched for articles on localized renal cell carcinoma from 2000 to 2008. In an effort to identify the records, the search descriptors: "renal cell carcinoma", "kidney neoplasm", were combined with the following terms: "radical nephrectomy", "nephron sparing surgery", "minimally invasive surgery", "radio frequency", "active surveillance" and "cryoablation". The databases search was conducted from March to April 2008. These terms were crossed, resulting in vast number of papers. Among the abstracts we identified, papers were selected on the basis of their clinical relevance with respect to the aim of the review.
The introduction of radical nephrectomy as the standard of care, together with earlier diagnosis provided by an increased frequency of radiological imaging, has made some progress in RCC management. This has translated into a small, but significant better global survival (7). (Figure-1)

\section{Radical Nephrectomy}

\section{Open Radical Nephrectomy}

In 1882, Czerny performed the first radical nephrectomy. However, high sepsis and mortality rates delayed the popularity of nephrectomy. In 1969, Robson et al., published one of the most recognized and cited articles concerning the standardization of radical nephrectomy (11).

The choice of surgical access for radical nephrectomy is determined by the size and location of the tumor, patients' anatomy, and the surgeon's preferences. Whatever the choice of incision, the radical treatment should follow accepted oncologic principles. Contemporary series of open radical nephrectomies (ORN) report acceptable complication rates between $2-7 \%$. The most common immediate complication is secondary hemorrhage (12).

Radical nephrectomy remains the most generally performed treatment for localized renal tumors. In clinical stage T3b tumors, radical nephrectomy with thrombectomy offers curative potential particularly in patients not exhibiting evidence of metastatic disease (13).

\section{Laparoscopic Radical Nephrectomy}

In 1990, Clayman accomplished the first laparoscopic radical nephrectomy (LRN) for a kidney tumor (14). After high initial costs and conquering the learning curve, Meraney and Gill concluded that this approach was $12 \%$ cheaper than open surgery (15). The well known benefits of laparoscopy have made this approach very attractive. Burgess et al. compared short outcomes of LRN and ORN and demonstrated less postoperative pain and an earlier return to normal activities (16).

Radical nephrectomies have been performed by laparoscopic approaches, emulating the open tech- 


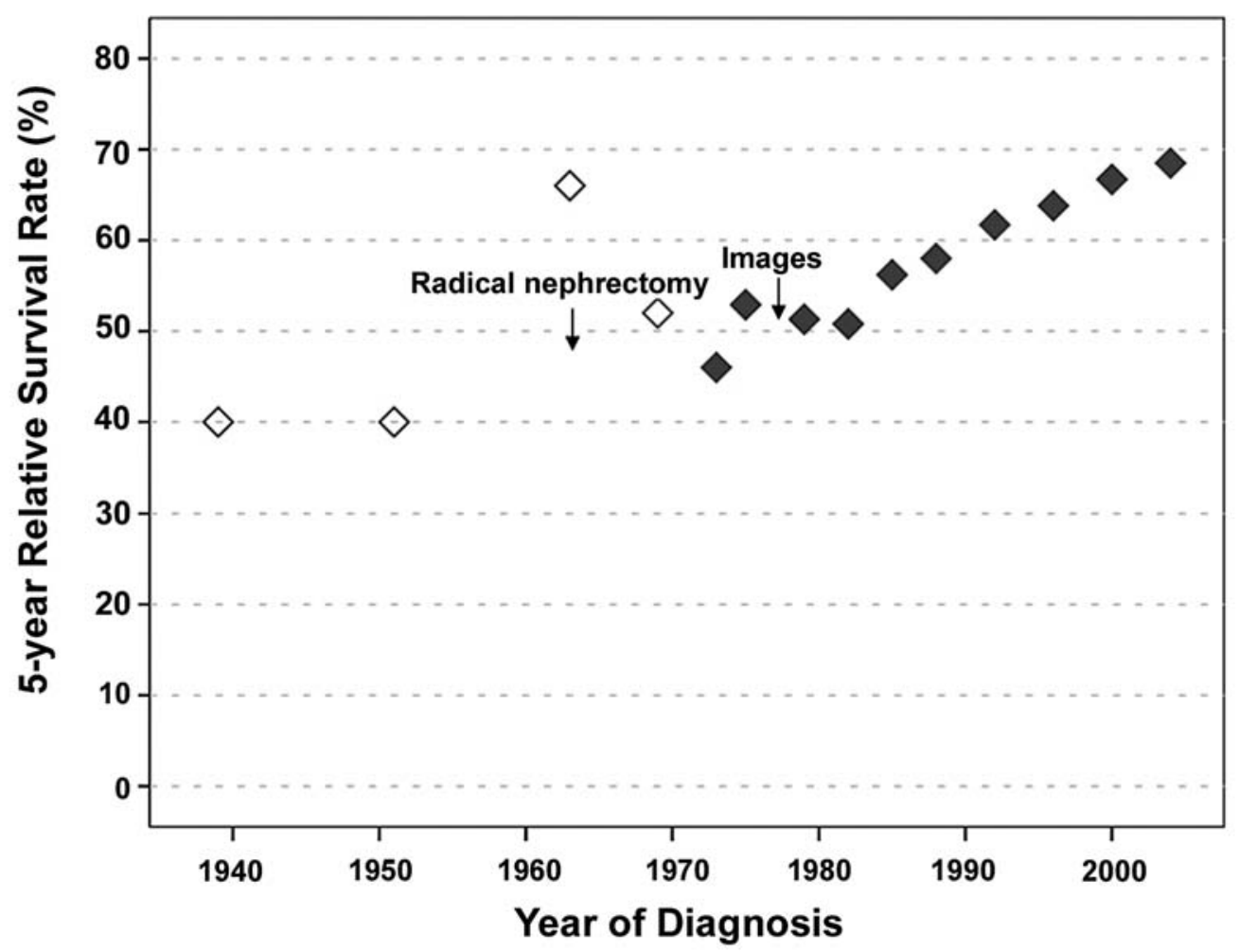

Figure 1 - The observed 5-year relative survival rate of the kidney cancer patients and the historical facts responsible for a better rate of survival. Source: J Urol, $1969 \diamond$ (ref. 11); - SEER Cancer Statistics Review, 2006 (ref. 2).

nique-with "en bloc" resection both feasible and desirable. Although it is possible to remove the specimen by morcellation, it impairs pathologic analysis and risks perforating the extractor bag. However, port site recurrences have been only rarely reported. Morcellation has been found to be a safe procedure, although contraindicated in patients with ascites (17).

Regarding long-term oncologic outcomes, several prospective cohorts compared laparoscopic versus open radical nephrectomy. Oncologic control after 3, 5, and 10 years of follow-up seems equivalent to open surgery (18-20).

LRN is an established standardized procedure for treatment of $\mathrm{T} 1, \mathrm{~T} 2$ and some $\mathrm{T} 3 \mathrm{aN} 0$ tumors. Nevertheless, despite some success of laparoscopy for more locally advanced tumors such as T3, open radical nephrectomy remains the gold-standard for these lesions (20). Today nephron sparing surgery is emerging as the new standard of care for small renal lesions (T1a and probably some T1b) (Table-1).

\section{Adrenalectomy}

Although ipsilateral adrenalectomy is feasible during radical nephrectomy, the real risk of adrenal invasion is low. Moreover, adrenal involvement can be detected preoperatively by computerized tomography or magnetic resonance image with a high sensitivity (21). However, false negative adrenal metastasis rate can be meaningful, particularly in upper pole masses and in the context of large renal masses. Direct tumor extension or metastatic involvement of the ipsilateral adrenal gland occurs in only $1.2-10 \%$ of surgical specimens. In a recent study, the adrenal involvement was found in $3.1 \%$ of 866 radical specimens (21). There are no reported prospective randomized studies examining the role of adrenalectomy in kidney cancer surgery. The low incidence of adrenal involvement and current imaging technology makes such a study unlikely.

\section{Lymphadenectomy}

Based on numerous published reports, such as: the UCLA experience and the EORTC 30881 
Table 1 - Indications for laparoscopic radical nephrectomy.

Tumor $<4 \mathrm{~cm}$, if it is not a candidate for partial nephrectomy

$\mathrm{T} 1, \mathrm{~T} 2-3 \mathrm{a} \mathrm{N} 0$ and $<10-12 \mathrm{~cm}$

randomized study, lymph node dissection is desirable only if preoperative imaging demonstrates enlarged lymph nodes. Lymph node involvement is associated with a poor prognosis although resection can increase survival when these patients are selected for adjuvant immunotherapy $(22,23)$. Because there is no benefit in prospective oncologic outcomes, lymphadenectomy is considered unnecessary in unsuspected lymph node metastases as assessed by pre-operative imaging.

\section{Partial Nephrectomy}

\section{Open Partial Nephrectomy (Nephron-Sparing Surgery - NSS)}

The first partial nephrectomy was performed in 1870 , by Simon, in a patient with hydronephrosis. The first oncologic partial nephrectomy was accomplished by Vizenz Czerny, successor of Simon in Heidelberg.

Today there is a debate about the accepted tumor size for partial nephrectomy. Patients with tumors of 4-7 cm with favorable anatomical characteristics are now treated conservatively (24). The complete removal of the tumor should be extended to have a negative margin. As regards the size of the normal parenchyma rim, some authors have reported that a macroscopic surgical margin of $0.5 \mathrm{~cm}$ is desirable, nonetheless the scientific literature supports that negative margin irrespective of size is adequate and safe (25). The survival data are excellent and 5-year cancer-specific survival is $90 \%$ (26). A retrospective analysis demonstrated a local recurrence rate of $7.5 \%$ $(0-12 \%)(27)$. The partial nephrectomy is criticized for its higher complication rate, chance of local recurrence due to incomplete resection, and because some of these tumors can be multifocal. However, recent series report low rates of local recurrence, even in patients with positive surgical margins (27).

In patients with a solitary kidney, bilateral tumors, inadequate renal function or Von Hippel-Lindau disease (VHL), partial nephrectomy has mandatory indications to avoid dialysis and possible renal transplantation. In VHL disease, patients frequently have multifocal tumors and multiple premalignant cysts. In these cases, nephron-sparing surgery is postponed with the intention of delaying the onset of renal insufficiency. These lesions are resected when the tumor reaches a determined size (28).

In 2006, Huang et al. demonstrated that radical nephrectomy is a risk factor for development of chronic renal disease (glomerular filtration rate, GFR $<60 \mathrm{~mL} / \mathrm{min}$ for $1.73 \mathrm{~m}^{2}$ ) when compared to patients undergoing partial nephrectomy (29). Studying a cohort of 662 patients, 171 had some degree of preoperative renal dysfunction, 50/287 and 142/204 patients developed CRD after partial and radical nephrectomy, respectively. The probability of not having chronic renal disease in 3 and 5 years was $80 \%$ and $67 \%$ in nephron-sparing surgery, respectively; and $35 \%$ and $23 \%$ in the radical surgery group $(\mathrm{p}<$ $0.0001)$. This functional result questions the role of radical nephrectomy, as the previous gold standard, in terms of best preserving long-term renal function for small cortical tumors $(29,30)$.

There are no prospective clinical trials that demonstrate the long-term oncological results of nephron-sparing surgery. However, the first randomized prospective phase III trial was led by the Genito-urinary Group of the European Organization for Research and Treatment of Cancer (EORTC) in collaboration with groups in North America (EORTC 30904). Van Poppel et al., randomized 541 patients with tumors less than $5 \mathrm{~cm}$ and a normal contralateral kidney (partial nephrectomy $\mathrm{PN}=268$ and Radical nephrectomy $\mathrm{RN}=273$ ). They concluded that the complication rate with partial surgery is slightly greater than in the radical procedure. The oncological results are not yet available (31) (Table-2).

Therefore, based on functional long-term outcomes and similar retrospective oncologic endpoints compared to radical procedure, elective NSS an 
Table 2 - Indications for nephron-sparing nephrectomy.

\author{
Formal Indications \\ Benign disease suspicion \\ Bourneville syndrome \\ Bilateral tumors \\ Angiomyolipoma \\ Cystic nephroma \\ Familial RCC \\ Solitary kidney \\ Oncocytoma \\ Complex cyst \\ Graft kidney \\ Von Hippel-Lindau disease \\ Relative Indications \\ (probable future chronic renal disease or threatened contralateral kidney) \\ Lithiasis \\ Vesicoureteral reflux \\ Arterial stenosis \\ Borderline renal function \\ Chronic pyelonephritis \\ Hypertension/diabetes

\section{Elective Indication} \\ Tumor with a normal contra-lateral kidney

\section{Controversial Indication} \\ Large (T2), central, multifocal and non-familial tumors
}

acceptable option for treat small RCC regardless of a higher complication rate. Nevertheless, the choice of invasiveness of the (laparoscopic or open) approach should not be considered the most important issue to select patients to radical or NSS procedures.

\section{Laparoscopic Nephron-Sparing Nephrectomy}

In some tertiary centers, the laparoscopic partial nephrectomy (LPN) is the standard technique for small cortical tumors $(<4 \mathrm{~cm})$. Concerning the surgical technique, the vascular anatomy is very important (32). The polar nephrectomy is indicated in polar tumors as the wedge resection is indicated for central tumors (33). With this approach, the artery and the vein can be clamped when convenient even without cooling the kidney. Maintaining the kidney in warm ischemia enables a resection of up to 30 minutes (34). When complicated resections are anticipated, the hilum clamping is advised in conjunction with previous mannitol (12.5g) 20\% administration and furosemide $(10 \mathrm{mg}) 5$ to 10 minutes before clamping. Cooling the kidney with ice (for about 25 minutes lowering the temperature to $\left.5-19^{\circ} \mathrm{C}\right)(35,36)$, helps prevent irreversible ischemic damage, thus making it possible longer resections up to 3 hours (37).
The most common complications of partial nephrectomy are hemorrhage (1.2-4.5\%), urinary fistula (1.4-17.4\%) and re-intervention (0-3.1\%) $(38,39)$. In the majority of cases, such complications can be managed conservatively, through endoluminal vascular or endourological techniques. The use of intraoperative ultrasound is a useful tool to evaluate depth and the presence of other tumors. Except in few centers, warm ischemia time is longer than in open surgery.

Permpongkosol et al. demonstrated that LPN has 5-year oncologic outcomes similar to open partial nephrectomy (40) (Table-3).

Even in modern series, there are heterogeneous populations between LPN and OPN, suggesting different indications. T1b tumors are more common in OPN than in LPN cohorts (41). Few studies report good initial results with hand-assisted technique and tele-robotic surgery (42).

\section{Minimally Invasive Techniques}

The minimally invasive techniques give new perspectives to the treatment of localized RCC, offering alternatives to conventional surgery. Currently, 
Table 3 - Published long-term outcomes for treatment of localized RCC regarding local recurrence, chronic renal disease (CRD) and cancer-specific survival.

\begin{tabular}{|c|c|c|c|c|c|}
\hline & Comparison & $\begin{array}{l}\text { Number of } \\
\text { Patients }\end{array}$ & $\begin{array}{c}\text { Local } \\
\text { Recurrence } \\
(\%)\end{array}$ & $\begin{array}{l}\text { CRD } \\
(\%)\end{array}$ & $\begin{array}{c}\text { 5-year Cancer } \\
\text { Specific Survival } \\
(\%)\end{array}$ \\
\hline Dunn et al., 2000 (69) & ORN vs. LRN & 33 vs. 61 & - & - & 92 vs. 90 \\
\hline Colombo et al., 2007 (19) & ORN vs. LRN & 43 vs. 45 & - & - & 92 vs. 90 \\
\hline Hemal et al., 2007 (18) & ORN vs. LRN & 71 vs. 41 & 0 vs. 0 & - & 94 vs. 95 \\
\hline Provet et al., 1991 (70) & OPN & 52 & 2.0 & - & 88 \\
\hline Delakas et al., 2002 (71) & OPN & 118 & 3.9 & 11 & 96 \\
\hline Fergany et al., 2000 (72) & OPN & 107 & 10.3 & 51 & 88 \\
\hline Hafez et al., 1999 (73) & OPN & 485 & 3.2 & - & 92 \\
\hline Becker et al., 2006 (74) & OPN $(<4 \mathrm{~cm})$ & 241 & 1.4 & - & 97 (10-years) \\
\hline Becker et al., 2006 (75) & OPN $(>4 \mathrm{~cm})$ & 69 & 5.8 & - & 100 (10-years) \\
\hline Lee et al., 2000 (76) & ORN vs. OPN & 183 vs. 79 & 0 vs. 0 & - & 100 vs. 100 \\
\hline Leibovich et al., 2004 (77) & ORN vs. OPN & 841 vs. 91 & 2 vs. 6 & - & 86 vs. 98 \\
\hline Patard et al., 2004 (25) & ORN vs. OPN & 1075 vs. 379 & 6 vs. 2 & - & 94 vs. 97 \\
\hline Corman et al., 2000 (78) & ORN vs. OPN & 1291 vs. 468 & - & 1.2 vs. 2.3 & - \\
\hline Huang et al., 2006 (29) & ORN vs. OPN & 204 vs. 287 & - & 33 vs. 77 & - \\
\hline Dash et al., 2006 (79) & ORN vs. OPN & 151 vs. 45 & - & 14 vs. 13 & - \\
\hline Lane et al., 2007 (66) & LPN & 58 & 1.7 & - & 100 \\
\hline Permpongkosol et al., 2006 (40) & OPN vs. LPN & 58 vs. 85 & - & 3.4 vs. 3.5 & 100 vs. 98 \\
\hline Gill et al., 2007 (80) & OPN vs. LPN & 1029 vs. 771 & - & 1.5 vs. 1.4 & 99 vs. 99 (3-years) \\
\hline Gill et al., 2005 (48) & Lap CRYO & 56 & 3.5 & - & 98 (3-years) \\
\hline Hegarty et al., 2006 (81) & Lap CRYO & 60 & 6.7 & - & 100 \\
\hline Sewell P et al., 2005 (45) & Lap CRYO & 103 & 10 & - & 97 (3-years) \\
\hline Davol et al., 2007 (47) & Lap CRYO & 48 & 12 & - & 100 (3-years) \\
\hline Weld et al., 2007 (49) & Lap CRYO & 81 & 1.2 & - & 100 (3-years) \\
\hline McDougal et al., 2005 (54) & Percut RFA & 16 & - & - & 100 (4-years) \\
\hline Stern et al., 2007 (52) & PN vs. RFA & 37 vs. 40 & 3 vs. 7 & - & 100 vs. 100 (3-years) \\
\hline
\end{tabular}

$O P N=$ open partial nephrectomy; ORN = open radical nephrectomy; $L P N=$ laparoscopic partial nephrectomy; $L R N=$ laparoscopic radical nephrectomy; Lap CRYO = laparoscopic cryoablation; Percut RFA = percutaneous radio frequency ablation.

great interest exists in renal ablations by radio-frequency and cryotherapy. Frequently, those therapies are reserved for patients with serious co-morbidities. However, their low morbidity and ability to preserve renal parenchyma make them promising techniques.

\section{Cryoablation}

Hypothermic ablation therapy $\left(-40^{\circ} \mathrm{C}\right)$ is performed through the introduction of a probe, whose function is to destroy the tissue by cellular damage from freezing, apoptosis, coagulation necrosis, and immunological action (43). The available devices use argon gas. Nonetheless, it is advisable that these procedures be properly guided by accurate imaging techniques. Some series have reported the safety of the technique, usually accomplished by laparoscopic or percutaneous means (Figure-2).

Hegarty et al., published a series of 164 cases treated by laparoscopic access. Forty-five of these 
patients had a 6 year follow-up, with general and cancer-specific survivals of $80 \%$ and $98 \%$, respectively. The local recurrence rate was $1.8 \%$ (44). There are no trials comparing long-term results of laparoscopic partial nephrectomy and laparoscopic cryoablation.

The percutaneous approach is even less invasive than laparoscopy and is able to be performed under local anesthesia and sedation. Sewell et al., studied 120 tumors treated by cryotherapy via percutaneous access with a cancer-specific survival of $97 \%$ and global survival of $90.2 \%$. With 35.5 months of follow-up, the local recurrence rate was $10 \%$ and approximately one-third of patients needed more than one session (45).

In a recent review, a complication rate of $14 \%$ was observed in 139 procedures (4 laparoscopic and 16 percutaneous). The most frequent complications were perinephric hematomas requiring blood transfusion, hematuria, paresthesias and abscesses. Renal dysfunction occurred in only 1 of 139 patients (46).

Three year oncological results have reported a cancer-free survival up to $97 \%$ (47-49). It can be concluded that cryoablation, using two freeze/thaw cycles, is a safe therapy in small tumors in patients with comorbidities (47).

Long-term results comparing conventional open partial nephrectomy to cryotherapy are expected.

\section{Radio Frequency Ablation}

Hyperthermic ablation therapy by radio frequency elevates the temperature of the tissues above $100^{\circ} \mathrm{C}$ by reaching an impedance of $200 \Omega$ created by an electrical current. It is also performed by introduction of a probe, causing coagulation necrosis.

Short and intermediate-term results have demonstrated the safety and effectiveness of this method in small renal tumors. Follow-up of 27 months exists, and global and cancer-specific survival rates of $92.3 \%$ and $98.5 \%$ respectively were observed (50).

Stern et al., published their results in 37 ASA 1-2 patients. Only one patient had a local recurrence in a period over 2 years and he was treated by radical nephrectomy without recurrence after 1 year followup (51). The same author compared intermediate-term results of partial nephrectomy and radiofrequency ablation and concluded that 3-year oncological outcomes were similar (52).

Gervais and colleagues published a series of 85 patients with the treatment of 100 tumors percutaneously. One local recurrence was seen and there were eleven complications-such as 2 blood transfusions. Indeed, $100 \%$ of the tumors smaller than $3 \mathrm{~cm}$ achieved complete ablation while only $25 \%$ of tumors greater than $5 \mathrm{~cm}$ were treated completely (53). In another paper of the same group, a cohort of 16 patients was reported with the longest term follow-up available (4.6 years). Five patients died of unrelated causes and the 5-year cancer specific-survival was 100\% (54).

Zagoria et al., obtained complete ablation (absence of contrast enhancement in the tumors on CT or MRI) in 116 of 125 tumors (93\%) although residual tumors were observed in 30\% of those larger than $3.7 \mathrm{~cm}$ in a follow-up of 13.8 months (55).

Centrally located tumors and those greater than $3 \mathrm{~cm}$ have been implicated as negative predictive factors for success. The observed complications are usually ureteral stenosis and urinomas. Residual tumors have been observed in nephrectomy specimens previously treated with radio-frequency ablation. There are concerns about viable tumor cells remaining after thermal ablation. However, such histological analyses were made in specimens previously treated with radiofrequency ablation just before the excision, therefore before complete coagulation necrosis had a chance to occur (56).

There are no systematic follow-up strategies after ablations of renal tumors. Usually, local recurrences or development of metastasis are assessed by images. The standard to define necrosis and response has been the absence of contrast enhancement in the lesion on post-treatment CT and MRI and not assessed by post-treatment serial biopsies. This arbitrary definition of radiographic success has been inadequate for determining complete ablation since positive biopsies have been reported in un-enhancing tumor beds (48). Therefore, current imaging techniques are quite limited to monitor and precise recurrences and repeated biopsies can be necessary to these purposes. Definitely, a more rigorous and uniform follow-up should be established, based on radiological findings and histological factors. Probably, 

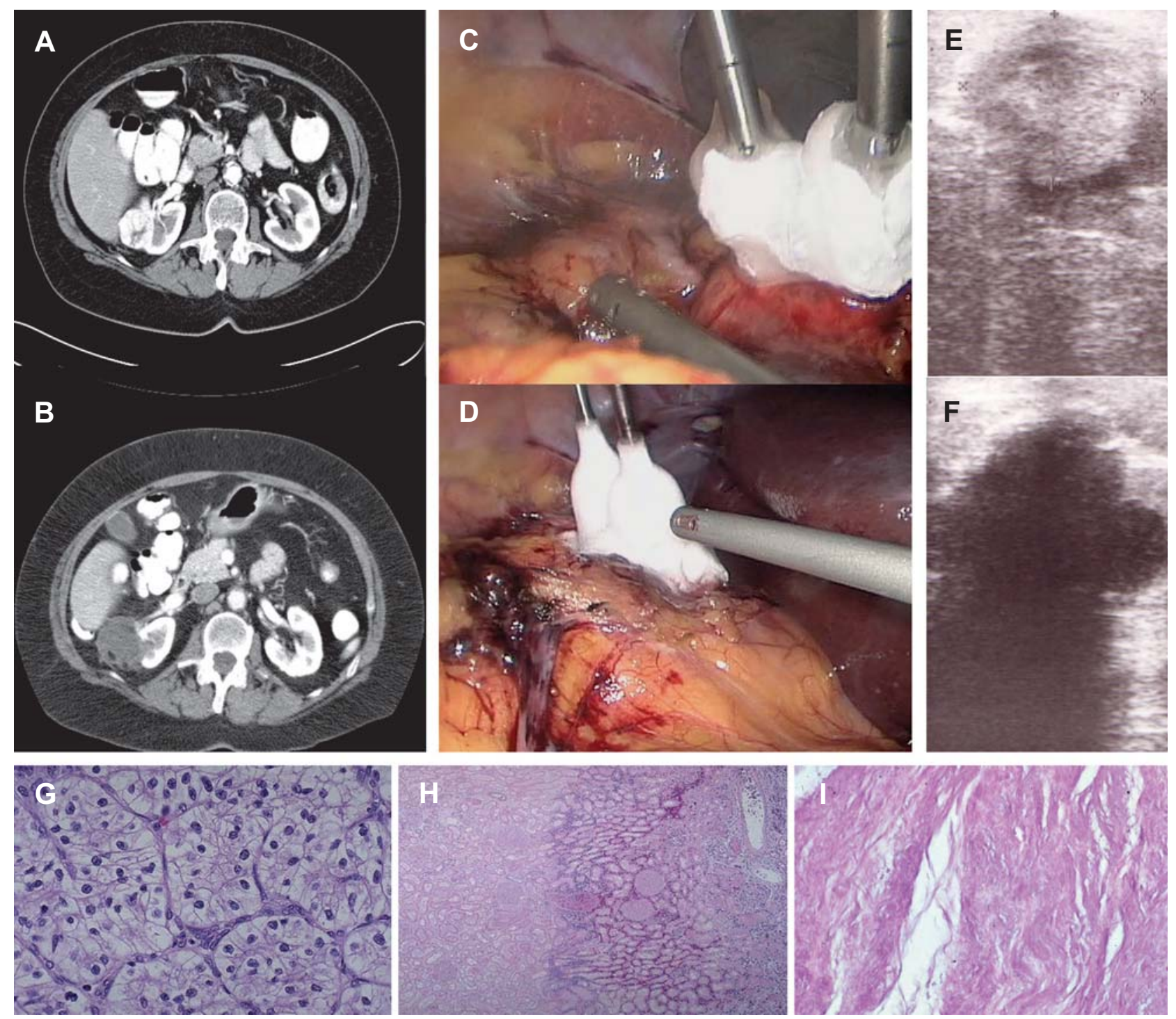

Figure 2 - Renal cell carcinoma cryoablation. A) and B) Preoperative and six months post cryoablation CT images demonstrating absence of enhancement in the ablation site equivalent to the peripherical antero-lateral tumor in the right kidney. C) and D) Laparoscopic cryoablation of a renal tumor with cryocare ${ }^{\circledR}$ device (courtesy of Dr. Schwartz, Southern Illinois University). E) and F) Intraoperative ultrasound confirming the correct position of cryosensors and cryoprobes and monitoring the freezing procedure (ice-ball). Photomicrographies illustrating the renal cell carcinoma $(G)$, an infarction area after cryotherapy $(H)$ and fibrosis in a follow-up biopsy (I).

in future, molecular markers will also be considered for this purpose. Ideally, surveillance after ablations as well as reporting of outcomes, technique and histological confirmation should be standardized to make possible comparisons of these ablative series with surgery.

\section{Neo Adjuvant Therapy for Localized Renal Cancer}

The role of neoadjuvant cytokines was investigated in patients with renal cancer undergoing radical nephrectomy. In a recent non-randomized controlled phase II trial, 120 consecutive patients 
were allocated alternately to 2 groups: perioperative immunomodulation with subcutaneous Interleukin-2 in the week before surgery and control (57). The two groups had similar characteristics. Median follow-up was 40 months. The results revealed a difference in the tumor-specific 1-year and 5-year survival rates of $98 \%$ vs. $81 \%$ and $86 \%$ vs. $73 \%(p=0.04)$ in treated vs. control groups. Despite this paper's non-randomized design, it signals a possible new approach in localized renal cell carcinoma. Future research in this field could be lead to the use of multi-targeted therapy as an option in selected patients with a high risk for recurrence.

\section{Adjuvant Therapy for Localized RCC}

Renal cell carcinoma expresses tumor antigens carbonic anhydrase IX and telomerase. Usually, these antigens promote an immune system response and eventually tumor destruction. These tumor antigens are available as potential targets for vaccination. Different mechanisms can make the tumor cells escape from immune surveillance. The cornerstone of tumor vaccination is to induce a tumor specific T-cell response.

Adjuvant tumor vaccination was reported in a randomized trial. A total of 553 patients were enrolled, comparing an autologous cancer cell vaccine. Jocham and colleagues have shown improvement in the 5-year progression-free survival for $\mathrm{T} 2-3 \mathrm{~N} 0-3$ tumors (58).

Randomized trials have shown no improvement in overall or disease-free survival with the adjuvant treatments radiotherapy, interferon, interleukin or BCG $(58,59)$. The new targeted therapies are fast becoming the standard treatment for metastatic RCC. Nonetheless, it is not yet known whether adjuvant angiogenesis inhibitors are more effective than observation in treating locally advanced renal cell carcinoma. Several adjuvant trials for high risk localized RCC are recruiting patients to evaluate the role of adjuvant G250Ab, sunitinib and sorafenib versus observation after complete excision of unfavorable RCC (ASSURE, SORCE and S-TRAC trials) (60-62). Preliminary results concerning patient-reported outcomes and safety are not expected before 2010 .

\section{Active Surveillance}

In spite of advances during the last decade, including a better understanding of tumor molecular biology, improved imaging, and minimally invasive procedures, approximately $30 \%$ of localized RCC will recur and progress. The current treatment framework considers that a better oncological outcome can be assured with early intervention. Hollingsworth et al., analyzing the SEER database that enrolled more than 34,500 tumors, concluded that the incidence of small tumors has increased $(<4 \mathrm{~cm})$ and represents the largest increase in annual incidence of RCC. Similarly, surgical treatment has increased (63). Nevertheless, even with preclinical tumor detection and the treatment of incidental tumors, the overall mortality of RCC has not been impacted. Hence, current assumptions of treatment are being reviewed and new concepts of management have been created. Active surveillance is being proposed to treat some of these indolent tumors, but there are doubts regarding this indolence (64).

The tenets of surveillance propose that small renal masses $(<3.5 \mathrm{~cm})$ with a slow annual growth rate $(<0.28 \mathrm{~cm} /$ year $)$ can be observed and should not be promptly treated (63). Unfortunately, tumor stage and growth kinetics are not reliable factors to predict a tumor's natural history; in part because of the heterogeneous range of tumors considered here (65).

Investigations from the Mayo Clinic showed that $46 \%$ of tumors less than $1 \mathrm{~cm}$ were benign (66). Also, Gill reported a cohort where the median tumor size was $3 \mathrm{~cm}$ and $32 \%$ of these lesions were benign, the great majority was cancerous (67).

Recently, a meta-analysis confirmed that the growth rate was not significantly different between oncocytomas and RCC variants. Although rare, metastatic disease was observed in 3 patients (1\%). Two of these patients became metastatic after the primary tumor reached $8 \mathrm{~cm}$ (54 and 111 months). Another patient had metastasis after a follow-up of 134 months. The pathological evaluation was provided in 131/286 (46\%) lesions and $92 \%$ confirmed a malignant pattern (64). Although renal biopsy should not be performed in the majority of patients, more recent studies have reported less complications and better accuracy.

Active surveillance should be restricted to elderly patients with co-morbidities or patients that 
refuse surgery. Thus, histological factors and molecular markers of progression are needed to improve the selection of patients for active surveillance.

Regardless of the approach, surgery remains the preferred standard of care for treating localized RCC. Complication rates of partial nephrectomies are not insignificant and ablative technologies are assuming a more prominent role. Recently, a meta-analysis compared oncological outcomes of these three strategies. Kunkle et al. analyzed 6,471 small renal masses described in 99 studies: 5,037 tumors were treated with nephron sparing surgery, 496 with cryoablation, 607 with radio frequency ablation and 331 were observed. The authors concluded that different groups have been treated by these strategies. This selection bias is clear when analyzing differences in tumor size, patient age, follow-up, and pathologic results. Although local control with ablation techniques has been inferior to nephron sparing surgery (radio-frequency 18 -fold and cryotherapy 7-fold), no significant differences were found concerning metastatic progression, even with surveillance (68).

\section{CONCLUSIONS}

Surgery has been mostly responsible for the improvement in survival in localized renal cell carcinoma. Unfortunately, surgery for advanced localized disease (T3 and T4) remains unsatisfactory with high recurrence rates (20 to $30 \%$ ). With a better understanding of the molecular basis of RCC the natural history can be predicted with improved accuracy, helping to identify high-risk tumors and establish targeted therapy for specific tumors.

Laparoscopic radical nephrectomy is the preferred treatment for localized renal masses (T1 and T2) deemed not amenable to partial nephrectomy (open or laparoscopic). The quality of life and preservation of renal function have now become important clinical issues. Therefore, attempts to achieve these goals have resulted in better clinical results and similar 10-year oncological outcomes for T1a lesions managed by partial nephrectomy, as well as T1b lesions $(<7 \mathrm{~cm})$ in favorable locations amenable to a partial nephrectomy..
Complete tumor resection must be advocated. Thus, all minimally invasive procedures should be compared to open surgery. Minimally invasive therapies, including cryosurgery and radio frequency ablation, by open, laparoscopic or percutaneous approaches are safe in patients with co-morbidities. The results obtained with minimally invasive therapies are promising. They are associated with a faster recovery, less pain, and decreased costs. However, long term oncologic efficacy remains to be demonstrated but is expected in the near future.

The role of other minimally invasive techniques, such as HIFU (high-intensity focused ultrasound), microwave thermotherapy, laser ablation, hypertonic solution instillation, and radio-surgery are uncertain and should at this time be considered experimental.

\section{CONFLICT OF INTEREST}

None declared.

\section{REFERENCES}

1. Parkin DM, Whelan SL, Ferlay J, Raymond L, Young J, (ed.), Cancer incidence in five continents. v. 7. Lyon: International Agency for Research on Cancer. 1997; (Scientific Publication 143).

2. Ries LAG, Harkins D, Krapcho M, Mariotto A, Miller BA, Feuer EJ, et al.: (ed.), SEER Cancer Statistics Review, 1975-2003, National Cancer Institute. Bethesda, MD. Available at: http://seer.cancer. gov/csr/1975_2003/index.html. Accessed June 20, 2007.

3. McLaughlin JK, Lipworth L, Tarone RE: Epidemiologic aspects of renal cell carcinoma.Semin Oncol. 2006; 33: 527-33.

4. Stephenson AJ, Chetner MP, Rourke K, Gleave ME, Signaevsky M, Palmer B, et al.: Guidelines for the surveillance of localized renal cell carcinoma based on the patterns of relapse after nephrectomy. J Urol. 2004; 172: 58-62.

5. Parkin DM, Bray F, Ferlay J, Pisani P: Global cancer statistics, 2002. CA Cancer J Clin. 2005; 55: 74108. 
6. Wunsch-Filho V: Insights on diagnosis, prognosis and screening of renal cell carcinoma. Sao Paulo Med J. 2002; 120: 163-4

7. Dall'Oglio MF, Srougi M, Gonçalves PD, Leite K, Nesrallah L, Hering F: Incidental and symptomatic renal tumors: impact on patient survival. São Paulo Med J. 2002; 120: 165-9.

8. Latorre MRDO: Cancer in Goiania: incidence and mortality from 1988 to 1997. Sao Paulo; 2001. Tese de livre docência - Faculdade de saúde pública da Universidade de São Paulo. Available at: http://www. teses.usp.br/teses/disponiveis/livredocencia/6/tde27042006-094006

9. Jemal A, Siegel R, Ward E, Hao Y, Xu J, Murray T, et al.: Cancer statistics, 2008.CA Cancer J Clin. 2008; 58: 71-96.

10. Klein FA, Gash JR, Waters B: Diagnosis And Staging of Renal Cell Carcinoma. In: Richie JP, D'Amico AV (eds.), Urologic Oncology. Philadelphia, Elsevier Sanders. 2005; pp. 173-94.

11. Robson CJ, Churchill BM, Anderson W: The results of radical nephrectomy for renal cell carcinoma. J Urol. 1969; 101: 297-301.

12. Corman JM, Penson DF, Hur K, Khuri SF, Daley $\mathrm{J}$, Henderson W, et al.: Comparison of complications after radical and partial nephrectomy: results from the National Veterans Administration Surgical Quality Improvement Program. BJU Int. 2000; 86: 782-9.

13. Portis AJ, Clayman RV: Should laparoscopy be the standard approach used for radical nephrectomy? Curr Urol Rep. 2001; 2: 165-70.

14. Clayman RV, Kavoussi LR, Soper NJ, Dierks SM, Merety KS, Darcy MD, et al.: Laparoscopic nephrectomy. N Engl J Med. 1991; 324: 1370-1.

15. Meraney AM, Gill IS: Financial analysis of open versus laparoscopic radical nephrectomy and nephroureterectomy. J Urol. 2002; 167: 1757-62.

16. Burgess NA, Koo BC, Calvert RC, Hindmarsh A, Donaldson PJ, Rhodes M: Randomized trial of laparoscopic v open nephrectomy. J Endourol. 2007; 21: 610-3.

17. Landman J, Clayman RV: Re: Port site tumor recurrences of renal cell carcinoma after videolaparoscopic radical nephrectomy. J Urol. 2001; 166: 629-30.

18. Hemal AK, Kumar A, Kumar R, Wadhwa P, Seth A, Gupta NP: Laparoscopic versus open radical nephrectomy for large renal tumors: a long-term prospective comparison. J Urol. 2007; 177: 862-6.

19. Colombo JR Jr, Haber GP, Aron M, Cocuzza M, Colombo R, Kaouk J, et al.: Oncological outcomes of laparoscopic radical nephrectomy for renal cancer. Clinics. 2007; 62: 251-6.

20. Mattar K, Finelli A: Expanding the indications for laparoscopic radical nephrectomy. Curr Opin Urol. 2007; 17: 88-92.

21. Paul R, Mordhorst J, Busch R, Leyh H, Hartung R: Adrenal sparing surgery during radical nephrectomy in patients with renal cell cancer: a new algorithm. J Urol. 2001; 166: 59-62.

22. Pantuck AJ, Zisman A, Dorey F, Chao DH, Han KR, Said J, et al.: Renal cell carcinoma with retroperitoneal lymph nodes: role of lymph node dissection. J Urol. 2003; 169: 2076-83.

23. Blom JH, van Poppel H, Marechal JM, Jacqmin D, Sylvester R, Schröder FH, et al.: Radical nephrectomy with and without lymph node dissection: preliminary results of the EORTC randomized phase III protocol 30881. EORTC Genitourinary Group. Eur Urol. 1999; 36: 570-5.

24. Miller DC, Hollingsworth JM, Hafez KS, Daignault S, Hollenbeck BK: Partial nephrectomy for small renal masses: an emerging quality of care concern? J Urol. 2006; 175: 853-7; discussion 858.

25. Patard JJ, Shvarts O, Lam JS, Pantuck AJ, Kim HL, Ficarra V, et al.: Safety and efficacy of partial nephrectomy for all T1 tumors based on an international multicenter experience. J Urol. 2004; 171: 2181-5.

26. Morgan WR, Zincke H: Progression and survival after renal-conserving surgery for renal cell carcinoma: experience in 104 patients and extended followup. J Urol. 1990; 144: 852-7; discussion 857-8.

27. Roth TJ, Leibovich BC, Cheville JC, Lohse CM, Cheville JC, Blute ML, Rochester MN: Features predictive of local recurrence following nephron-sparing surgery for renal cell carcinoma. J Urol. 2006; 175: 241. (abstract no. 742).

28. Steinbach F, Novick AC, Zincke H, Miller DP, Williams RD, Lund G, et al.: Treatment of renal cell carcinoma in von Hippel-Lindau disease: a multicenter study. J Urol. 1995; 153: 1812-6.

29. Huang WC, Levey AS, Serio AM, Snyder M, Vickers AJ, Raj GV, et al.: Chronic kidney disease after nephrectomy in patients with renal cortical tumours: a retrospective cohort study. Lancet Oncol. 2006; 7: 735-40.

30. McKiernan J, Simmons R, Katz J, Russo P: Natural history of chronic renal insufficiency after partial and radical nephrectomy. Urology. 2002; 59: 816-20.

31. Van Poppel H, Da Pozzo L, Albrecht W, Matveev V, Bono A, Borkowski A, et al.: A prospective randomized EORTC intergroup phase 3 study comparing the 
complications of elective nephron-sparing surgery and radical nephrectomy for low-stage renal cell carcinoma. Eur Urol. 2007; 51: 1606-15.

32. Sampaio FJ: Anatomical background for nephronsparing surgery in renal cell carcinoma. J Urol. 1992; 147: 999-1005.

33. Frank I, Colombo JR Jr, Rubinstein M, Desai M, Kaouk J, Gill IS: Laparoscopic partial nephrectomy for centrally located renal tumors. J Urol. 2006; 175: $849-52$.

34. Derweesh IH, Novick AC: Mechanisms of renal ischaemic injury and their clinical impact. BJU Int. 2005; 95: 948-50.

35. Uzzo RG, Novick AC: Nephron sparing surgery for renal tumors: indications, techniques and outcomes. J Urol. 2001; 166: 6-18.

36. Novick AC: Nephron-sparing surgery for renal cell carcinoma. Annu Rev Med. 2002; 53: 393-407.

37. Marberger M. In situ cooling of the kidney. In: Marberger M, Dreikorn K (ed.), Renal preservation. Baltimoree, Williams \& Wilkins; 1983. pp. 38-63.

38. Herr HW: Partial nephrectomy for unilateral renal carcinoma and a normal contralateral kidney: 10 -year followup. J Urol. 1999; 161: 33-4; discussion 34-5.

39. Becker F, Siemer S, Humke U, Hack M, Ziegler M, Stöckle M: Elective nephron sparing surgery should become standard treatment for small unilateral renal cell carcinoma: Long-term survival data of 216 patients. Eur Urol. 2006; 49: 308-13.

40. Permpongkosol S, Bagga HS, Romero FR, Sroka M, Jarrett TW, Kavoussi LR: Laparoscopic versus open partial nephrectomy for the treatment of pathological T1N0M0 renal cell carcinoma: a 5-year survival rate. J Urol. 2006; 176: 1984-8; discussion 1988-9.

41. Guillonneau B, Bermúdez H, Gholami S, El Fettouh H, Gupta R, Adorno Rosa J, et al.: Laparoscopic partial nephrectomy for renal tumor: single center experience comparing clamping and no clamping techniques of the renal vasculature. J Urol. 2003; 169: 483-6.

42. Kawauchi A, Yoneda K, Fujito A, Okihara K, Soh J, Naitoh Y, et al.: Oncologic outcome of hand-assisted laparoscopic radical nephrectomy. Urology. 2007; 69: 53-6.

43. Chosy SG, Nakada SY, Lee FT Jr, Warner TF: Monitoring renal cryosurgery: predictors of tissue necrosis in swine. J Urol. 1998; 159: 1370-4.

44. Hegarty NJ, Gill IS, Desai MM, Remer EM, O’Malley $\mathrm{CM}$, Kaouk JH: Probe-ablative nephron-sparing surgery: cryoablation versus radiofrequency ablation. Urology. 2006; 68(Suppl 1): 7-13.
45. Sewell P, Shingleton W: Five-year treatment success and survival of patients treated with percutaneous IMRI guided and monitored renal cell carcinoma cryoablation. BJU Int. 2004; 94: 106. (abstract MP1609).

46. Johnson DB, Solomon SB, Su LM, Matsumoto ED, Kavoussi LR, Nakada SY, et al.: Defining the complications of cryoablation and radio frequency ablation of small renal tumors: a multi-institutional review. J Urol. 2004; 172: 874-7.

47. Davol PE, Fulmer BR, Rukstalis DB: Long-term results of cryoablation for renal cancer and complex renal masses. Urology. 2006; 68(Suppl 1): 2-6.

48. Gill IS, Remer EM, Hasan WA, Strzempkowski B, Spaliviero M, Steinberg AP, et al.: Renal cryoablation: outcome at 3 years. J Urol. 2005; 173: 19037.

49. Weld KJ, Figenshau RS, Venkatesh R, Bhayani SB, Ames CD, Clayman RV, et al.: Laparoscopic cryoablation for small renal masses: three-year follow-up. Urology. 2007; 69: 448-51.

50. Varkarakis IM, Allaf ME, Inagaki T, Bhayani SB, Chan DY, Su LM, et al.: Percutaneous radio frequency ablation of renal masses: results at a 2-year mean followup. J Urol. 2005; 174: 456-60; discussion 460.

51. Stern JM, Park S, Anderson JK. Kidney tumor radiofrequency abaltion: experience in ASA I and ASA II patients. J Urol 2006; 175: 27(abstract no. 81).

52. Stern JM, Svatek R, Park S, Hermann M, Lotan Y, Sagalowsky AI, et al.: Intermediate comparison of partial nephrectomy and radiofrequency ablation for clinical T1a renal tumours. BJU Int. 2007; 100: 287-90.

53. Gervais DA, McGovern FJ, Arellano RS, McDougal WS, Mueller PR: Radiofrequency ablation of renal cell carcinoma: part 1, Indications, results, and role in patient management over a 6-year period and ablation of 100 tumors. AJR Am J Roentgenol. 2005; 185: 64-71.

54. McDougal WS, Gervais DA, McGovern FJ, Mueller PR: Long-term followup of patients with renal cell carcinoma treated with radio frequency ablation with curative intent. J Urol. 2005; 174: 61-3.

55. Zagoria RJ, Traver MA, Werle DM, Perini M, Hayasaka S, Clark PE: Oncologic efficacy of CT-guided percutaneous radiofrequency ablation of renal cell carcinomas. AJR Am J Roentgenol. 2007; 189: 42936.

56. Rendon RA, Kachura JR, Sweet JM, Gertner MR, Sherar MD, Robinette M, et al.: The uncertainty of 
radio frequency treatment of renal cell carcinoma: findings at immediate and delayed nephrectomy. J Urol. 2002; 167: 1587-92.

57. Klatte T, Ittenson A, Röhl FW, Ecke M, Allhoff EP, Böhm M: Perioperative immunomodulation with interleukin-2 in patients with renal cell carcinoma: results of a controlled phase II trial. $\mathrm{Br} \mathrm{J}$ Cancer. 2006; 95: 1167-73.

58. Jocham D, Richter A, Hoffmann L, Iwig K, Fahlenkamp D, Zakrzewski G, et al.: Adjuvant autologous renal tumour cell vaccine and risk of tumour progression in patients with renal-cell carcinoma after radical nephrectomy: phase III, randomised controlled trial. Lancet. 2004; 363: 594-9.

59. Galligioni E, Quaia M, Merlo A, Carbone A, Spada A, Favaro D, et al.: Adjuvant immunotherapy treatment of renal carcinoma patients with autologous tumor cells and bacillus Calmette-Guèrin: five-year results of a prospective randomized study. Cancer. 1996; 77 : 2560-6.

60. ASSURE: Adjuvant sorafenib or sunitinib for unfavorable renal carcinoma. Available at: http://clinicaltrials.gov/ct2/show/NCT00326898.

61. SORCE: A Phase III Randomized double-blind study comparing sorafenib with placebo in patients with resected primary renal cell carcinoma at high or intermediate risk of relapse. Available at: http:// clinicaltrials.gov/ct2/show/NCT00492258.

62. Sunitinib Treatment of Renal Adjuvant Cancer (STRAC): A Randomized Double Blind Phase 3 Study of Adjuvant Sunitinib VS. Placebo in Subjects At High Risk of Recurrent RCC. Available at: http:// clinicaltrials.gov/ct2/show/record/NCT00375674.

63. Hollingsworth JM, Miller DC, Daignault S, Hollenbeck BK: Rising incidence of small renal masses: a need to reassess treatment effect. J Natl Cancer Inst. 2006; 981: 1331-4.

64. Chawla SN, Crispen PL, Hanlon AL, Greenberg RE, Chen DY, Uzzo RG: The natural history of observed enhancing renal masses: meta-analysis and review of the world literature. J Urol. 2006; 175: 425-31.

65. Lane BR, Samplaski MK, Herts BR, Zhou M, Novick AC, Campbell SC: Renal mass biopsy--a renaissance? J Urol. 2008; 179: 20-7.

66. Lerner SE, Hawkins CA, Blute ML, Grabner A, Wollan PC, Eickholt JT, et al.: Disease outcome in patients with low stage renal cell carcinoma treated with nephron sparing or radical surgery. 1996. J Urol. 2002; 167: 884-9.

67. Gill IS, Desai MM, Kaouk JH, Meraney AM, Murphy DP, Sung GT, et al.: Laparoscopic partial nephrec- tomy for renal tumor: duplicating open surgical techniques. J Urol. 2002; 167: 469-7; discussion 475-6.

68. Kunkle DA, Egleston BL, Uzzo RG: Excise, ablate or observe: the small renal mass dilemma--a metaanalysis and review. J Urol. 2008; 179: 1227-33; discussion 1233-4.

69. Dunn MD, Portis AJ, Shalhav AL, Elbahnasy AM, Heidorn C, McDougall EM, et al.: Laparoscopic versus open radical nephrectomy: a 9-year experience. J Urol. 2000; 164: 1153-9.

70. Provet J, Tessler A, Brown J, Golimbu M, Bosniak M, Morales P: Partial nephrectomy for renal cell carcinoma: indications, results and implications. J Urol. 1991; 145: 472-6.

71. Delakas D, Karyotis I, Daskalopoulos G, Terhorst B, Lymberopoulos S, Cranidis A: Nephron-sparing surgery for localized renal cell carcinoma with a normal contralateral kidney: a European three-center experience. Urology. 2002; 60: 998-1002.

72. Fergany AF, Hafez KS, Novick AC: Long-term results of nephron sparing surgery for localized renal cell carcinoma: 10-year followup. J Urol. 2000; 163: 442-5.

73. Hafez KS, Fergany AF, Novick AC: Nephron sparing surgery for localized renal cell carcinoma: impact of tumor size on patient survival, tumor recurrence and TNM staging. J Urol. 1999; 162: 1930-3.

74. Becker F, Siemer S, Humke U, Hack M, Ziegler M, Stöckle M: Elective nephron sparing surgery should become standard treatment for small unilateral renal cell carcinoma: Long-term survival data of 216 patients. Eur Urol. 2006; 49: 308-13.

75. Becker F, Siemer S, Hack M, Humke U, Ziegler M, Stöckle M: Excellent long-term cancer control with elective nephron-sparing surgery for selected renal cell carcinomas measuring more than $4 \mathrm{~cm}$. Eur Urol. 2006; 49: 1058-63; discussion 1063-4.

76. Lee CT, Katz J, Shi W, Thaler HT, Reuter VE, Russo P: Surgical management of renal tumors $4 \mathrm{~cm}$. or less in a contemporary cohort. J Urol. 2000; 163: 730-6.

77. Leibovich BC, Blute ML, Cheville JC, Lohse CM, Weaver AL, Zincke H: Nephron sparing surgery for appropriately selected renal cell carcinoma between 4 and $7 \mathrm{~cm}$ results in outcome similar to radical nephrectomy. J Urol. 2004; 171: 1066-70.

78. Corman JM, Penson DF, Hur K, Khuri SF, Daley J, Henderson W, et al.: Comparison of complications after radical and partial nephrectomy: results from the National Veterans Administration Surgical Quality Improvement Program. BJU Int. 2000; 86: 782-9. 
79. Dash A, Vickers AJ, Schachter LR, Bach AM, Snyder ME, Russo P: Comparison of outcomes in elective partial vs radical nephrectomy for clear cell renal cell carcinoma of 4-7 cm. BJU Int. 2006; 97: 939-45.

80. Gill IS, Kavoussi LR, Lane BR, Blute ML, Babineau D, Colombo JR Jr, et al.: Comparison of 1,800 lapa- roscopic and open partial nephrectomies for single renal tumors. J Urol. 2007; 178: 41-6.

81. Hegarty NJ, Kaouk JH, Spaliviero M, Desai MM, Novick AC, Remer EM: Renal cryoablation: 5 year outcomes. J Urol. 2006; 175: 351 (Abst. \#1091).

Accepted after revision: September 3, 2008

\section{Correspondence address:}

Dr. Flavio Heldwein

Rua Altamiro Guimaraes, 360 / 504

Florianópolis, SC, 88015-510, Brazil

Fax: + 5548 3223-0816

E-mail: flavio.lobo@gmail.com

\section{EDITORIAL COMMENT}

In this review, the authors provide a comprehensive review of the current scientific literature on the management of localized renal tumors. The authors have adequately depicted that the management of small renal masses is no longer a simplistic discussion with patients that "the kidney needs to be removed" but rather that a spectrum of treatment choices are currently available from minimally invasive treatment modalities such as percutaneous radiofrequency ablation or cryotherapy, to nephron sparing surgery (laparoscopic, robotic assisted, open partial nephrectomy), extirpative surgery (laparoscopic or open radical nephrectomy), and active surveillance (for well-selected patients committed to a rigorous surveillance strategy and accepting of the potential risk of local, regional, and systemic progression).

One point that I would like to emphasize is that partial nephrectomy remains the "gold standard" approach for the management of localized renal masses deemed amenable to partial excision with negative surgical margins. The benefits of partial nephrectomy are increasingly being shown in terms of long-term renal function. The surgical approach used in performing a partial nephrectomy (i.e. open, pure laparoscopic, or robotic assisted laparoscopic) should depend on patient related, tumor specific, surgeon skill, and available hospital resources. The issue that is clear is that patient and case selection is of primordial importance.

Non-surgical, minimally invasive approaches to renal masses i.e. percutaneous cryotherapy or radiofrequency ablation are appealing to patients not ideally suited for aggressive surgical management and presenting with small renal masses amenable to this modality. Patients considering such minimally invasive approaches must be informed and accepting that long-term data on the effectiveness of these approaches are currently lacking and furthermore, patients must be committed to frequent radiologic imaging studies following the ablative procedure particularly within the first year (1,3,6,9, and 12 months). Patients must also be informed that a residual enhancing renal mass post-ablation may require repeated therapy (with either the same modality or another form of therapy).

What is clearly illustrated in the present discussion is that it is no longer appropriate for urologists to offer radical nephrectomy alone as the sole form of 


\section{Renal Cell Carcinoma Management}

treatment for a suspected localized renal mass. Patients must be educated and guided along this spectrum of currently available treatment armamentarium. With this knowledge at hand, patients are able to decide for themselves which modality is best suited for them.
Furthermore, our knowledge is evolving and future discoveries and technological advances will impact our treatment options for a localized renal mass, our role will be to keep abreast of these advances and make them readily available to our patients.

Dr. Philippe E. Spiess Department of Interdisciplinary Oncology Moffitt Cancer Center University of South Florida Tampa, Florida, USA E-mail:Philippe.Spiess@moffitt.org 